\title{
PENDAMPINGAN WIRAUSAHA MANDIRI MELALUI PEMBUATAN POT DARI HANDUK BEKAS DI RW 07 KELURAHAN BULIANG
}

\section{ENTREPRENEURSHIP ASSISTANCE THROUGH POT MAKING BY USING UNUSABLE TOWELS AT RW 07 BURIAHAN BULIANG}

\author{
Amrullah Rasal \\ ${ }^{I}$ Imu Pemerintahan, Fakultas Ilmu Sosial dan Ilmu Politik, \\ Universitas Riau Kepualuan, Batam, Indonesia \\ rasal@fisip.unrika.ac.id
}

\begin{abstract}
Abstrak
Usaha kreatif mandiri merupakan kegiatan yang dapat mengembangkan soft skill dalam kehidupan masyarakat. Usaha kreatif mandiri dapat menumbuhkan jiwa wirausaha di masyarakat, ditengah semakin sulitnya perekonomian saat ini. Pengembangan usaha kreatif masyarakat dilakukan di wilayah RW 07 Kelurahan Buliang. Usaha kreatif menjadi trend positif bagi masyarakat dalam mengembangkan soft skill masyarakat. Fenomena usaha kreatif ini dimanfaat oleh tim pengabdian dalam mebuka peluang usaha bernilai ekonomis. Dalam hal ini memanfaatkan handuk bekas sebagai bahan alternatif dalam membuat pot. Handuk bekas merupakan salah satu bahan limbah yang dapat di daur ulang dan dijadikan sebagai barang yang bernilai ekonomis. Tujuan dari pengabdian ini adalah upaya usaha kreatif mandiri masyarakat RW 07 dalam meningkatkan pendapatan ekonomi di wilayah tersebut.Hasil kegiatan wirausaha mandiri ini dapat meningkatkan daya kreatif masyarakat RW 07 terutama ibu rumah tangga dalam meningkatkan pendapatan ekonomi rumah tangga.
\end{abstract}

Kata Kunci: Wirausaha, Ekonomi Kreatif, Handuk Bekas

\begin{abstract}
A creative effort is an activity that can develop soft skill in people's life. Societies' creativeness can grow entrepreneurship spirit in society, die to the moneter cisis now adays. societies' creativeness development was done at RW 07 Buliang. Creative efforts became a positive trend in developing societies' soft skill. The phenomenon of this creative effort was utilized by the devotion team in opening a high economic value business. In this case. utilizing unusable towels was as an alternative material in making pots. unusable towels were one of the waste materials that can be recycled and used as economic value goods. The purpose of this dedication was the effort of creative effort of $R W$ 07 Societies in increasing the income. The result of this activity could increase the spirit of societies' creativeness at $R W 07$, especially housewife in increasing income.
\end{abstract}

Keywords: Entrepreneurship, Creative Economy, Unusable Towels.

\section{PENDAHULUAN}

Kegiatan Pengabdian Pada Masyarakat merupakan suatu kegiatan intrakurikuler yang memadukan dharma Pendidikan, dan Penelitian, sekaligus dalam satu kegiatan. Kegiatan 
Pengabdian Pada Masyarakat merupakan bagian integral dari Tri Dharma Perguruan Tinggi yang menekankan pada aspek pengalaman belajar dan menghubungkan konsep - konsep akademis dengan realita kehidupan masyarakat. Program ini merefleksikan pengetahuan teori yang disinergikan dengan pengalaman di lapangan sebagai unjuk kerja yang mampu mengembangkan soft skill, mematangkan kepribadian dan menumbuhkan rasa percaya diri dalam kehidupan sosial kemasyarakatan.

Berangkat dari hal tersebut, kegiatan pengabdian pada masyarakat melalui usaha kreatif mandiri merupakan kegiatan yang dapat mengembangkan soft skill dalam kehidupan masyarakat. Usaha kreatif mandiri dapat menumbuhkan jiwa wirausaha di masyarakat, ditengah semakin sulitnya perekonomian saat ini. Upaya untuk menumbuhkembangkan jiwa wirausaha di masyarakat merupakan hal yang penting sebagai pondasi perekonomian suatu Negara. Wirausaha merupakan potensi pembangunan, baik dalam jumlah maupun dalam mutu wirausaha itu sendiri. Apalagi sekarang ini, Indonesia dihadapkan pada masih sedikitnya wirausahawan dan mutunya belum bisa dikatakan hebat, sehingga pembangunan wirausaha Indonesia merupakan persoalan mendesak bagi suksesnya pembangunan.

Pelaksanaan kegiatan wirausaha dilakukan di RW 07 Kelurahan Buliang. Secara administratif, Perumahan Muka Kuning Indah 1 RW 7 Kelurahan Buliang terletak diwilayah kecamatan Batu Aji, Batam, Kepulauan Riau dengan posisi dibatasi oleh wilayah. Sebelah Utara berbatasan dengan Kecamatan Sagulung, sebelah Selatan berbatasan denganKelurahan Tanjung Riau Kecamatan Sekupang, sebelah Timur berbatasan dengan Kelurahan Kibing Kecamatan Batu Aji, dan sebelah Barat berbatasan dengan Kelurahan Bukit Tempayan Kecamatan Batu AJi. Luas wilayah RW 7 adalah 1000km² dengan jumlah penduduk yang berjumlah \pm 1000 jiwa terdiri dari 120 Kepala Keluarga (KK), dan tersebar di 7 RT.

Daerah Rw 7 merupakan bagian dari perumahan Muka Kuning Indah 1 (Genta 1) yang letaknya sangat strategis karena dekat dengan pasar,sekolahan, dan jalan raya. Rata-rata masyarakat yang tinggal dirw 7 didominasi oleh pekerja baik yang sudah berkeluarga maupun yang masih lajang. Hal ini menjadikan suatu prospek tersendiri bagi masyarakat sekitar menjadikan rumah mereka atau membangun rumah mereka untuk dijadikan sebagai sebuah kontrakan/kos-kosan bagi para pekerja di daerah Batam. Dengan harga yang cukup bervariasi berkisar 350.000- 800.000 dapat dijadikan suatu tambahan tersendiri bagi masyarakat sekitar. Selain itu, rata-rata warga rw 7 memiliki usaha sendiri-sendiri, seperti rumah makan, warung,salon, dll. 
Masyarakat RW 7 juga membuat bank sampah,bank sampah tersebut di beri nama "Bank Sampah Samara", hal ini menunjukkan trend positif bagi masyarakat disamping menambah pendapatan bagi masyarakat juga dapat membantu menjaga dan meningkatkan kebersihan lingkungan. Bank sampah merupakan konsep pengumpulan sampah kering dan dipilah serta memiliki manajemen layaknya perbankan tapi yang di tabung bukan uang melainkan sampah. Sampah-sampah yang di ambil merupakan sampah berbahan dasar plastik yang sulit terurai sehingga dapat di manfaatkan menjadi barang yang dapat bernilai ekonomis.

Berdasarkan fenomena yang terjadi di masyarakat RW 07, Tim PPM melihat ada peluang usaha dalam memanfaatkan barang bekas tersebut. Dalam hal ini memanfaatkan handuk bekas sebagai bahan alternatif dalam membuat pot. Handuk bekas merupakan salah satu bahan limbah yang dapat di daur ulang dan dijadikan sebagai barang yang bernilai ekonomis. Tujuan dari pengabdian ini adalah upaya usaha kreatif mandiri masyarakat RW 07 dalam meningkatkan pendapatan ekonomi di wilayah tersebut.

\section{METODOLOGI}

Kegiatan Pendampingan Wirausaha Mandiri Membuat Pot dari handuk bekas dilaksanakan di RW 07 Keluaragan Buliang. Kegiatan ini dilaksanakan pada tanggal $26-27$ September 2017 dengan melibatkan 26 mahasiswa.

Adapun metode pelaksanaannya adalah:

1. Melakukan pertemuan dengan perangkat RW dan RT serta masyarakat setempat guna membahas kegiatan wirausaha mandiri membuat pot dari handuk bekas mengenai tempat dan waktu pelaksanaan. Dalam rapat ini juga sekaligus memberikan pengetahuan kepada masyarakat mengenai pemanfaataan limbah sampah menjadi barang yang bernilai ekonomis yang dapat dijual melalui media online.

2. Melakukan observasi di wilayah RW 07 untuk menentukan lokasi pelaksanaan kegiatan tersebut.

3. Melakukan persiapan bahan dan alat untuk kegiatan tersebut.

\section{PEMBAHASAN}

Kegiatan pembuatan pot dari handuk bekas ini dilaksanakan di Fasum (Fasilitas Umum) RW 07 dan diikuti oleh ibu-ibu rumah tangga di lingkungan tersebut. Keggiatan ini 
dilaksanakan 2 hari. Dimana hari pertama adalah pelatihan cara membuat pot dari handuk bekas. Pada hari kedua, peserta mengkreasikan sendiri pot yang mereka buat dari handuk bekas tersebut. Masyarakat RW 12 terutama Ibu-Ibu dan remaja putri antusias ikut dalam kegiatan tersebut. Terbukti, banyaknya jumlah peserta yang ikut dalam kegiatan tersebut.

Setelah pelatihan selesai dilakukan, kegiatan selanjutnya adalah memberikan pengetahuan mengenai cara memasarkan barang tersebut lewat media sosial, seperti instagram dan facebook. Pelaksanaan kegiatan wirausaha mandiri melalui pembuatan pot dari bekas handuk dapat dijadikan suatu tambahan penghasilan tersendiri untuk ibu-ibu dilingkungan tersebut, mereka dapat mengkreasikan bentuk sesuai kreatifitas mereka, ditambah lagi ibu-ibu dilingkungan tersebut cukup aktif dimedia sosial sehingga dapat memasarkan produk tersebut melalui media sosial.

\section{KESIMPULAN}

Dari kegiatan pengabdian yang telah dilaksanakan, maka dapat disimpulkan bahwa:

1. Dalam kegiatan ini, perlu pendekatan persuasif untuk mengajak masyarakat RW 07 berpartisipasi dalam wirausaha mandiri melalui pembuatan pot dari handuk bekas.

2. Melalui kegiatan wirausaha mandiri ini dapat meningkatkan daya kreatif masyarakat RW 07 terutama ibu rumah tangga dalam meningkatkan pendapatan ekonomi rumah tangga.

\section{REFERENSI}

Profil Kecamatan Batu Aji. 2017. Website www.arsipskpd.batam.go.id 